\title{
TOURISM DEVELOPMENT IN CONTEMPORARY CENTRAL AND EASTERN EUROPE: CHALLENGES FOR THE INDUSTRY AND KEY ISSUES FOR RESEARCHERS
}

\author{
Derek R. Hall* \\ Seabank Associates, Maidens, Scotland - Seabank, 3 Turnberry Road, Maidens. Ayrshire KA26 9NN, Scotland UK
}

\begin{abstract}
Within the context of tourism development in the countries of contemporary Central and Eastern Europe, this paper briefly discusses the challenges for industry and key issues for researchers within six broad topic areas. These are: climate change adaptation and mitigation; integration with sustainable development strategies; coping with globalization; differentiation/ uniqueness; innovation; and collaboration/ partnership/ networking. Practical cases are drawn from Western European experience to exemplify potential opportunities, and recent published research is identified to inform fruitful research directions. It is concluded that challenges and issues are similar across Europe, and that those relating to climate change adaptation and mitigation are, in the wider context, the most important to understand and address.
\end{abstract}

Key words: Industry challenges, Research issues, Europe, Destinations, Climate change.

\section{Aims and objectives}

With reference particularly to contemporary Central and Eastern Europe (CEE), this paper draws on experience from Western Europe and mostly Englishlanguage literature, and aims to:

- raise questions about how we look at contemporary tourism development;

- highlight some major challenges for the tourism industry in CEE;

- indicate some of the key issues for tourism researchers in CEE; and

- draw some critical conclusions.

In so doing this paper intends to highlight some of the contradictions and paradoxes arising from current trends. It begins and closes by posing a key question.

\section{Opening question}

Looking forward not back, given that it is now more than twenty years since the events of $1989-91$, is it time to stop talking about 'postsocialism' when

\footnotetext{
* Correspondence address:

Email: derekhall.seabank@virgin.net
}

referring to the current context? This is suggested because, in the author's opinion, use of this term:

- appears to perpetuate a 'victim' (of communism) culture/mentality;

- implies, misleadingly, a (conceptual) homogeneity of 'postsocialist' states (just as many Westerners had negative Cold War perceptions of a homogeneous (EE); and

- may mean very little to new generations who have little remembrance or experience of life under state socialism.

This terminological question should also be set against the ages old geographical (geopolitical?) debate yet ever-pertinent issue of 'regional' identity. It is this author's belief that although the CEE countries shared certain similar characteristics of centrally planned economies within the 1943-89 period, and despite the existence of overarching mechanisms such as the Council for Mutual Economic Achievement (CMEA or COMECON) and the Warsaw Treaty Organisation (WTO or Warsaw Pact) during that time, the countries' cultural, environmental and historical differences - some subtle, others obvious - acted both to interact with their similarities and to maintain individual distinctiveness between them (and in some cases between the regions within a country). This was no 
less true for tourism development, which reflects issues of cultural and natural environmental heritage, levels of economic development, and degrees of spatial accessibility.

Similarly, 'post-socialist' 'transformations' / 'transitions' and beyond have emphasised different characteristics and interpretations despite attempted impositions of 'one solution fits all' policies, pathways and mentalities from some Western institutions. The literature on transition and tourism development reflecting the potential paradox of similarity and differentiation is now extensive (e.g. Hall, 2004b, 2008; Hall et al., 2006).

In relation to the above-stated aims of the paper, its objectives will be focused largely on the tourism destination.

\section{Major destination challenges and key research issues}

There appear to be at least two key critical issues for contemporary tourist destinations in the countries of CEE, although they are far from being unique to this part of Europe:

- they need to respond to increasingly complex and different market segments' demands, and at different times; and

- the nature and impacts of tourist behaviour is becoming less rooted in 'places' and more responsive to 'activities', thereby potentially reducing the role of individual destinations and the promotion of a 'sense of place'.

Destination place marketing is therefore confronted with a number of tensions and challenges that can be set within wider contemporary challenges and issues of tourism development in the countries of CEE (e.g. Hall, 2004a; Hughes and Allen, 2005).

Within this context this paper attempts to briefly evaluate key common challenges and issues for tourism development in the countries of CEE under the following six headings. The author appreciates that there will very many more challenges and issues that are specific to individual or groups of destinations, while the six discussed below overlap and interact and will have varying levels of importance.
1. Climate change adaptation and mitigation
2. Integration with sustainable development strategies
3. Coping with globalization
4. Differentiation/uniqueness
5. Innovation
6. Collaboration/partnership/networking

\section{Climate change: adaptation and mitigation}

Three significant general trends might be expected when considering the likely nature and impacts of climate change in the region (e.g. Becken and Hay, 2007; Simpson et al., 2008):

- warmer, longer summers but greater variations in extremes of temperature, precipitation, humidity and pressure;

- reduction/loss of snow at existing winter resorts: at best resulting in shorter and less predictable winter sports seasons; and

- increased/new insect activity and the possibility of malaria and other (semi-) tropical diseases moving northwards.

These trends in their turn will affect such issues as water availability, changing biogeographical resources and crop growing capacity.

While only conjecture at this stage, and acknowledging that, of course, other factors such as financial circumstances will also be important, significant potential responses to changing climatic conditions for the countries of CEE might include:

- 'staycations': a return to domestic tourism in western and northern Europe at the expense of international travel;

- variations in seasonal patterns of activity with less predictability and therefore less continuity for forward planning at destinations;

- more southerners travelling north, perhaps at the expense of domestic tourism in southern Europe;

- a shift from some long-haul to regional tourism within Europe;

- emerging Asian and Latin American markets may find Europe less attractive as a destination.

There would therefore appear to be a number of key research issues for adaptation to changing environmental conditions and tourism markets' responses to them (but see also Gössling and Hall, 2006):

- to identify appropriate, sustainable 'non-climate sensitive' tourism activities and attractions: diversification within tourism, especially where current activity patterns may be unsustainable in changing climatic circumstances;

- to identify potential alternative economic strategies: diversification beyond tourism and to recognize that tourism may decline or even disappear in certain destination areas;

- to closely monitor global, regional and national tourism trends - numbers, flows, activities, seasonal patterns - to identify and be able to 
respond quickly to the market impacts of changing climatic (and other, such as economic) circumstances; and

- to develop and consolidate such relevant collaborative research projects as the EU FP6 CLAVIER programme (www.clavier-eu.org/).

The work of Stefan Gössling and collaborators particularly in relation to long-haul tourism ecological footprints and to mitigation is a good example of research being undertaken elsewhere in Europe (e.g. Gössling et al., 2002, 2005, 2006; Simpson et al., 2008).

\section{Integration with sustainable development strategies}

Particularly with the pressures of climatic change, tourism cannot be viewed in isolation, but tourism development needs to be an integral part of wider economic, social and environmental development strategies. This can be exemplified in the muchquoted role of place marketing, of which tourism is just one part, which should have the power to encourage 'livability, investibility and visitability' (Kotler et al., 1993), thereby emphasising tourism's integrative role with other aspects of socio-economic development.

Tourism should assist in bringing sustainability into mainstream development policy.

Geographers would appear to be well positioned to lead both of these interrelated processes.

Unfortunately, the reality is that sustainability ideals receive lower priority from decision makers in times (and places) of economic difficulty. Therefore, the well-known mantras need to be emphasized and repeated to decision-makers:

- sustainable development must be seen to be economically rewarding. In particular, businesses need to be convinced of the financial and ethical rewards of sustainable behaviour; and

- education and training need to emphasize holistic thinking.

All too obviously the 'greenwashing' of tourism has become commonplace: e.g. many 'sustainable tourism' promoters ignore the impacts of air travel to the destination but instead concentrate on the 'sustainability' of the destination. But the destination may represent just a small element of tourists' ecological impact. For example, Gössling et al. (2002) calculated that in long-haul tourism from Europe to Mauritius 97 per cent of the ecological footprint of tourists results from resource consumption and emissions of their long-haul flight, and only three per cent from activity at the destination.

Key research issues for integration indicated by examining the direction of recently published work in Europe include:

- the regional potential of rural tourism and conservation and their contribution to sustainable rural development as part of 'territorial capital' (van Berkel and Verburg, 2011);

- the further conceptualization and case study exemplification of 'territorial sustainability' (Péti, 2011); and

- the nature, role and potential of urban-rural fringe areas, which fall - spatially and functionally - between studies of rural and urban tourism. In particular, how can such areas be better integrated into wider tourism development processes and how far is their 'contiguity capital' currently undervalued (Hall, 2011; Hall et al. 2011)?

\section{Coping with 'Globalization'}

Prioritizing the wide and variable range of issues to be addressed here is a considerable task for decision makers. Looking at some of the spatial impacts of EU enlargement, for example, strategies are required to respond to the nature and impacts of:

- intensified, and new patterns of capital mobility, including investment from non-EU sources, such as hotel investment from Russia and the Middle East;

- intensified, and new patterns of labour mobility to tourism honeypots;

- a stimulation of increased transit traffic within the EU; and

- significant new patterns of, and constraints upon, movement across (new) EU external borders: e.g. with Russia, Belarus, Ukraine.

Some of the more general globalization challenges, albeit having specific characteristics and impacts in different countries and their regions, include:

a) host-guest tensions/conflicts, e.g. through 'outsiders' buying 'second' homes, land and other property stimulating local shortages, inflation and exclusion, and the need to balance the rights and responsibilities of 'hosts' and 'guests';

b) the importance of sustaining high quality education and training: e.g. for awareness and understanding of an increasingly diverse range of foreign guests' (cultures') needs and attitudes. However, for example in rural tourism there may need to be a 
balance between 'professionalism' and the 'authenticity' of a 'hobbyist' approach that can be attractive in farm accommodation and service provision;

c) a growing ethical awareness: a 'climate of corporate responsibility' has encouraged the growth of codes of practice and behaviour since the late 1980s, but codes have become so numerous (e.g. over 400 in ecotourism) that they can lose their value and actually be counterproductive (Orams, 1995). Further, 'corporate social responsibility' (CSR) has become an overused cliché amongst tourism businesses (following a similar propagandist and often misleading (and dishonest) over-use of 'sustainability'). Therefore there needs to be an awareness and realistic application of ethical behaviour that can generate a positive response from increasingly sophisticated visitors;

d) saturation and related carrying capacity issues. There is still a poor understanding and lack of research on how overcrowded honeypots may repel potential return visits and degrade the image of major destinations such as Amsterdam, Prague and Florence (and particular attractions within those places, e.g. Van Gogh Museum, Charles Bridge, Uffizi Gallery) (e.g. see Woodside et al., 2007);

e) emergence of 'new' tourism regions. This can be stimulated by such contemporary factors as new low-cost airline activity at regional airports, changes to internal administrative systems, improved regional infrastructure, increasing sophistication of 'strategic place marketing', changing fashions in tourism demand and activities, and the generation of new types of attractions;

f) other impacts of budget airlines ('low-cost carriers': LCCs). Drastically reducing fare levels and extending the low end of the market for air travel has encouraged potential destination image problems in some locations where hen/stag party groups, weekend binges and sex tourism have been generated. This, of course, can present major problems for the branding of destination countries and regions seeking a positive new or rejuvenated image. Further, LCCs are mobile and very cost sensitive and can easily move routes away from a particular airport/region which may have come to depend upon them for inward flows of visitors, income and employment opportunities;

g) rejuvenating 'traditional' activities /attractions: e.g. spa, health, wellness and holistic tourism: a growing global leisure-based self-conscious fitness lifestyle (Erfurt-Cooper and Cooper, 2009). Rapidly gaining a position in high-value markets, holistic retreats offer routes to the reconciliation of body, mind and spirit, emphasizing tourism's concern with an inner journey to find oneself as well as the outer journey to seek different cultures and environments (the Other) (e.g. see Smith, 2003). But almost paradoxically, such 'holistic' wellness tourism, being wholly focused on the self, contrasts sharply with the holism and altruism of sustainable development ideals. What is required for sustainable forms of wellness tourism to be built upon traditional spa tourism? Are traditional, natural resource-linked locations adequate to meet $21^{\text {st. }}$ century demands?

Overall, a key research issue would appear to be the nature of the key factors that influence ways in which decision makers prioritize the national and regional importance of particular globalization impacts, coupled to the obvious requirements of:

- sustaining and further developing the positive dimensions of tourism development, such as consolidating the ethical basis of sustainable ecoand wildlife tourism; while

- minimising/removing negative aspects of globalization impacts, such as the (mostly) negative destination image that much 'night tourism' can bring (e.g. see Clift and Carter, 200o).

\section{Differentiation/ uniqueness}

Destination promotion and place branding require a unique selling point (USP) especially as destinations may be viewed as one aspect of 'lifestyle' (e.g. see Murphy et al., 2007). When tourists make choices about destinations they may be making conscious lifestyle statements: they are 'buying into an emotional relationship' with destinations and/or activities. Therefore destinations need to be positioned to occupy a niche to reflect the collective importance of such relationships.

Because of their size cities usually have a variety of niche activities and attractions that can be employed in contributing to a promotional brand image to capture such emotional relationships. Conversely, however, the wide range of stakeholders with interests in a large destination may find it difficult to agree on a place brand or image, resulting, for example, in competing website marketing images (e.g. see Vanolo, 2008).

It is usually more difficult for small towns and rural areas to promote 'uniqueness', although their activities and attractions are likely to be more focused than in a city. One way of differentiating a small destination is by developing a 'theme' through encouraging the clustering of similar types of 
activities to produce a distinctive local specialization where it is realistic to do so.

An apposite example of this 'theming' can be taken from the mostly rural Dumfries and Galloway region of south-west Scotland. In this attractive area, collaboration between the local authority, local economic development agency and private businesses has helped to theme three rural market towns that have been able to attract complementary activities and act as a focus for regional specialisation:

- an 'artists' town': Kirkudbright (www.kirkudbright.co.uk). Since at least the nineteenth century artists have come to stay, live and paint in this attractive small town located on an estuary because of its pure air and good light. Tourists can now visit the houses, studios and sites that earlier and contemporary artists have worked in. Original and copies of art works are available. Complementary activities such as sculptors, ceramicists, art bookshops and the provision of artists' materials have been attracted here. Interest in both art history and local history have been stimulated. The rural region also hosts regular arts festivals that help to spread visitation and visitor spending both spatially and temporally;

- a 'book town': Wigtown (www.wigtownbooktown.co.uk). Long-known for having one of the largest second-hand bookshops in Scotland, Wigtown since the 1990 s has attracted a number of other bookshops, selling both new and secondhand books, and acting as both specialist and generalist providers. Complementary activities such as printers and bookbinders, as well as an annual literary festival and a food fair have also acted as complementary attractions. Book towns have been popular in Western Europe and North America for several decades (e.g. see Seaton, 1996, 1999), and literary festivals held in them have often become important 'hallmark events' (Hall and Weiler, 1992); and

- a 'food town': Castle Douglas (www.cdfoodtown.org). Located in a rich agricultural area this designation has emphasised the provision and consumption of quality food. It has helped to retain and enhance traditional food shops such as butchers and bakers, and has encouraged the local development of organic production, awareness of 'healthy eating' and a stronger sense of regional identity.

Two related key research issues would appear to be:

- how to determine sustainable local uniqueness, particularly in smaller and rural destinations, that can be employed as the basis of place marketing, while recognising the impacts of tourist behaviour that may be becoming less rooted in 'places' and more responsive to 'activities'; and

- generating models and exemplars of good practice from those destinations in which the wide range of stakeholders with divergent interests have found it possible to collaborate and agree on promoting a particular place brand or image.

\section{Innovation}

Innovation capacity in tourism has lacked good research and understanding (Hall and Williams, 2008). Innovation is vital in destination product development, image formation, promotion and marketing.

Place and activity promoters need to seek added value. How is this derived and recognised?

Since the 1990s some marketing emphasis has been placed on the 'experience economy': deriving added value through providing extra experience when delivering goods and services (Pine and Gilmour, 1998). Ironically, this has taken place at the same time as 'vicarious experience' - experiencing something at second-hand - has influenced tourist behaviour responding to an emotional attachment to aspects of popular culture. In particular, 'screen tourism' and its impact has gained much attention (e.g. Kim and Richardson, 2003; Beeton, 2005; Roesch, 2009).

In recent decades, television, film and video/DVD (and of course the Internet and I-technology) have tended to overtake the role of the written word as key vehicles for reaching mass audiences with place images. Movies and TV soaps have re-emphasized the role of place in visitors' lifestyle aspirations, such that viewers want to physically and emotionally associate with places and events they have seen on the screen.

Earlier research (e.g. Tooke and Baker, 1996; Riley et al., 1998) suggested that tourist visits to movie locations as destinations could increase in the first year after a film's release by 30-90 per cent. It suggested that this effect may last four years or more, especially with TV repeats and the availability of DVDs. For the locations of TV soaps this can be a long-term phenomenon.

Significantly for regional regeneration purposes, many attractions visited as a result of movies or TV soaps have not previously been attractions, and some have been areas in decline: for example, the industrial streets of Sheffield (UK) that are featured in the bitter comedy film about de-industrialised unemployed men becoming male strippers, The Full Monty (see www.youtube.com/watch?v=nA3 $\mathrm{W}_{3} 6 \mathrm{JVn}$ ). 
There are two important sets of relationships here, both direct and indirect, within which destination innovation can flourish.

1. Direct: local and regional economic development organizations encourage film companies to shoot films in their area. The local area gains economic benefits through extra spending during the filming: for catering, temporary accommodation, land, building and vehicle rental, and the hiring of film extras.

The 'demonstration effect' may also be significant whereby one movie company filming in an area can set a precedent for others to follow. For example, the Isle of Man government provides a development fund to help attract movie makers, such that there have been around fifty film productions located on this island since 1995, and screen tourists represent over 100,000 bed nights each year (www.gov.im/tourism/attractions/film.xml).

2. Indirect: tourism marketing and promotion can take advantage of the popularity of particular places or regions because they have been featured in a movie or TV soap seen by mass audiences: e.g. the British Tourist Authority (BTA) established a 'Movie map' website of the UK providing details, on a crossreferencing basis, of films and TV soaps shot in the UK, and their locations (www.visitbritain.com).

Ystad in southern Sweden, a medieval town of 27,0oo people, has been the setting for a TV series (25 episodes, with DVDs): Wallander - based upon a fictional detective (author Henning Mankell). It has been popular in Sweden for 15 years and there are also German and UK TV versions. The books upon which the character and location are based have been translated into many languages.

In and around Ystad there are Wallander town and regional trails, including 'murder walks' whereby tourists can relive story lines and actually walk in the footsteps of their hero, acting out the scripts and plotlines of particular episodes (Reijnders, 2009; www.ystad.se). Partly as a consequence of the success of the Wallander films a regional centre for film production has been established here (Sjöholm and Jönsson, 2009).

Key research questions that are raised by innovation issues include:

- how do tourism firms understand the role of internationalization as innovation?

- what are key innovations for successful tourism development? For example, the potential for linkages and collaboration between TV/film industries and tourism destination promotion: e.g. see O'Connor and Macionis, 2011; also Kim et al., 2009);
- what are the determinants for effective knowledge transfer?

- And, not least, what role do tourists play (a) as active participants in the co-production of innovation, and (b) as 'pioneers' signalling opportunities for tourism businesses (Williams and Shaw, 2011)?

\section{Collaboration/partnership/networking}

Traditional marketing theory and brand promotion emphasize competition between destinations/attractions, but there is now increasing emphasis on the importance of partnerships, collaboration and network development (a) between destinations in a region, and (b) between stakeholders within a destination (e.g. Bramwell and Lane, 2000; March and Wilkinson, 2009; Beritelli, 2011).

The key ingredients in these relationships are obvious, but their nurturing and sustaining may be often overlooked:

- clusters: to attract a critical mass of activity acting as honeypots, and providing links to other attractions and activities;

- partnerships: entrepreneurs working together to support and benefit from clusters to ensure a (fair?) diffusion of benefits;

- networks: efficient use of information technology to support partnerships, exchange information, promote events and products; and

- knowledge transfer: for example, through learning by observation/imitation, labour mobility and inter-firm exchanges (Weidenfeld et al., 2010).

Key Research Issues include the need for longerterm studies on the importance of such qualities as mutual trust, understanding, communication, and information exchange for (spatial and structural) linkages, networks and collaboration within and between destinations and their activities/attractions. Also, investigations are needed to establish the most appropriate spatial scale for the analysis of cluster and network relationships.

\section{Conclusions}

1. The contemporary challenges and opportunities for tourism development and research in the countries of Central and Eastern Europe may be little different from those of Western and Northern Europe. 
2. Shared knowledge and values are important in sustaining both a healthy tourism sector and valuable research programmes.

3. Overall, the challenges of climate change present the most important longer term issues for both tourism practitioners and researchers.

4. Adaptation and mitigation require both diversification within tourism and diversification beyond, and perhaps without, tourism. The latter potential reality in particular needs to be confronted and planned for.

5. But equally there are many opportunities within strategies for sustainable tourism development to take advantage of changing lifestyles and market demands and to employ innovative ways to express local, regional and national distinctiveness that can be attractive for potential visitors, investors and residents.

6. Tourism is an inseparable part of sustainable regional development - it has the potential to lead in ensuring that sustainability is central to regional and national development strategies.

7. As researchers, teachers and consultants, geographers should be very well equipped to be in the forefront of informing such strategies.

But, for the paper's concluding question, is there not a paradox here, since all thinking academics should be trying to reduce their carbon footprint? And one way we can do this is by encouraging others and ourselves to actually travel less.

\section{Bibliography}

Becken, S\& Hay, JE 2007, Tourism and Climate Change, Channel View,Clevedon UK.

Beeton, S 2005, Film-induced Tourism, Channel View,Clevedon UK.

Beritelli, P 2011, 'Cooperation among prominent actors in a tourism destination', Annals of Tourism Research, vol.38, no.2, p.6o7-629.

Bramwell, B\&Lane, B(eds.)20oo, Tourism Collaboration and Partnerships: Politics, Practice and Sustainability, Channel View, Clevedon UK.

Clift, S \& Carter, S 200o, Tourism and Sex: Culture, Commerce and Coercion, Pinter,London.

Erfurt-Cooper, P \& Cooper, M 2009, Health and Wellness Tourism, Channel View, Clevedon UK.

Ghodsee, K 2005, The Red Riviera: Gender, Tourism, and Postsocialism on the Black Sea, Duke University Press,Durham NC and London.

Gössling, S, Borgström Hansson, C, Hörstmeier, O \&Saggel, $\mathrm{S}$ 2002, 'Ecological footprint analysis as a tool to assess tourism sustainability', Ecological Economics, vol.43, p.199-211.

Gössling, S, Peeters, P, Ceron, JP, Dubois, G, Patterson, T\&Richardson, RB 2005, 'The eco-efficiency of tourism', Ecological Economics, vol.54, nr.4, p.417-434.
Gössling, S \& Hall, CM 2006, 'Uncertainties in predicting tourist flows under scenarios of climate change', Climatic Change, vol. 79, nr.3-4, p.163-173.

Hall, CM\&Weiler, B 1992, Hallmark Tourist Events: Impacts, Management and Planning, Belhaven, London.

Hall, CM \& Williams, AM 2008, Tourism and Innovation, Routledge, London.

Hall, D 2004a, 'Branding and national identity: the case of Central and Eastern Europe', in N Morgan, A Pritchard \& R Pride, (eds.), Destination Branding: Creating the Unique Destination Proposition, 111-127, $2^{\text {nd }}$ edn,Elsevier,Amsterdam.

Hall, D(ed.)2004b, Tourism and Transition: Governance, Transformation and Development, CABI Publishing,Wallingford UK.

Hall, D 2008, 'From 'bricklaying' to 'bricolage': transition and tourism development in Central and Eastern Europe', Tourism Geographies, vol.10, nr.4, p.410-428.

Hall, D 2011, 'Tourism in semi-rural environments: sustainability issues and experience from the Baltic States', in DVL Macleod \& SA Gillespie, (eds.), Sustainable Tourism in Rural Europe: Approaches to Development, Routledge, 75-89, London.

Hall, D, Birtwistle, M \& Gladstone, J2011, 'Semi-rural marginal areas, 'inbetween-ness' and tourism integration in South-West Scotland', Tourism Recreation Research, vol.36, nr.1, p.3-14.

Hall, D, Smith, M \&Marciszewska, B (eds.)20o6, Tourism in the New Europe: The Challenges and Opportunities of EU Enlargement, CABI Publishing,Wallingford UK.

Hughes, H \& Allen, D 2005, 'Cultural tourism in Central and Eastern Europe: the views of induced image formation agents", Tourism Management, vol.26, p.173183.

Kim, H \& Richardson, SL 2003, 'Motion picture impacts on destination images', Annals of Tourism Research, vol.30, nr.1, p.216-237.

Kim, S, Long, P \& Robinson, M 2009, 'Small screen, big tourism: the role of popular Korean television dramas in South Korean tourism', Tourism Geographies, vol.11, nr.3, p.308-333.

Kotler, P, Haider, DH \& Rein, I 1993, Marketing Places: Attracting Investment, Industry and Tourism to Cities, States and Nations, The Free Press,New York.

March, R \& Wilkinson, I 2009, 'Conceptual tools for evaluating tourism partnerships', Tourism Management, vol.30, nr.3, p.455-462.

Murphy, L, Moscardo, G \&Benckendorff, P 2007, 'Using brand personality to differentiate regional tourism destinations', Journal of Travel Research,vol.46,nr.1, p. 514 .

O'Connor, N\&Macionis, $\mathrm{N}$ (eds.) 2011, 'How can the filminduced tourism phenomenon be sustainably managed?', Worldwide Hospitality and Tourism Themes, vol.3, nr.2, special issue.

Orams, MB 1995, 'Towards a more desirable form of ecotourism', Tourism Management, vol.16, nr.1, p.3-8.

Péti, M 2011, 'A territorial understanding of sustainability in public development', Environmental Impact Assessment Review, online, awaiting publication at www.elsevier.com/locate.eiar paper EIAR-05726. 
Pine, BJ \& Gilmour, JH 1998, 'Welcome to the experience economy', Harvard Business Review, July-August, p.97105.

Reijnders, S 2009, 'Watching the detectives', European Journal of Communication, vol.24, nr.2, p.165-181.

Riley, R, Baker, D\& Van Doren, CS 1998, 'Movie induced tourism',Annals of Tourism Research, vol.23, nr.4, p.919935 .

Roesch, S 2009, The Experience of Film Location Tourists, Channel View, Clevedon UK.

Roman, D 2001, 'Gendering Eastern Europe: pre-feminism, prejudice, and East-west dialogues in post-communist Romania', Women's Studies International Forum, vol.24, nr.1, p.53-66.

Seaton, AV 1996, 'Hay on Wye, the mouse that roared: book towns and rural tourism', Tourism Management, vol.17, nr.5, p.379-382.

Seaton, AV 1999, 'Book towns as tourism developments in peripheral areas', International Journal of Tourism Research, vol.1, nr.5, p.389-399.

Simpson, MC, Gössling, S, Scott, D, Hall, CM\&Gladin, E 2008, Climate Change Adaptation and Mitigation in the Tourism Sector: Frameworks, Tools and Practices, CAB International,Wallingford UK.
Sjöholm, C \&Jönsson, LE 2009, 'MördarjaktiYstad', Rig.KulturhistoriskTidskrift, vol.9o, nr.4, p.205-220.

Smith, MK 2003, 'Holistic holidays: tourism and the reconciliation of body, mind, spirit', Tourism Recreation Research, vol.28, nr.1, p.103-108.

Tooke, N\& Baker, M 1996, 'Seeing is believing. The effect of film on visitor numbers in screened locations', Tourism Management, vol.17, p.87-94.

vanBerkel, DB \&Verburg, PH 2011, 'Sensitising rural policy: assessing spatial variation in rural development options for Europe', Land Use Policy, vol. 28, p.447-459.

Vanolo, A 2008, 'The image of the creative city: some reflections on urban branding in Turin',Cities, vol.25, nr.6, p.370-382.

Weidenfeld, A, Williams, AM \& Butler, R 2010, 'Knowledge transfer and innovation amongst attractions', Annals of Tourism Research, vol.37.nr.3, p.604-626.

Williams, AM \& Shaw, G 2011, 'Internationalization and innovation in tourism', Annals of Tourism Research, vol.38.nr.1, p.27-51.

Woodside, AG, Cruickshank, BF \&Dehuang, N 2007, 'Stories visitors tell about Italian cities as destination icons', Tourism Management, vol.28, nr.1, p.162-174. 